\section{Journal of Computer Networks, Architecture and High Performance Computing}

Volume 3, Number 2, July 2021

https://doi.org/10.47709/cnahpc.v3i2.1154
Submitted : Nop 2, 2021

Accepted : Nop 3, 2021

Published : Nop 4, 2021

\title{
Determining Goods Delivery Priority for Transportation Service Companies Using SAW Method
}

\author{
Sumaizar ${ }^{1)}$, Kalvin Sinaga ${ }^{2)}$, Eko Deswin Siringo-ringo ${ }^{3)}$, Victor Marudut Mulia Siregar ${ }^{4}$ \\ 1)3)Sekolah Tinggi Akuntansi dan Manajemen Indonesia, Indonesia \\ 2)4)Politeknik Bisnis Indonesia, Indonesia \\ ${ }^{1)}$ sumaizar@gmail.com, ${ }^{2)}$ kal.sinaga@gmail.com, ${ }^{3)}$ ekodeswin10@yahoo.com, ${ }^{4)}$ victor.siregar2@gmail.com
}

\begin{abstract}
This research was conducted aiming to overcome the problem of the effectiveness of the delivery of goods by the Cendrawasi Expeditionary Company which at this time still does not use a decision support system approach. For the process of delivering goods to customers to be carried out effectively, a decision support system is designed that functions to determine the priority of goods to be delivered first. This problem is solved by designing a decision support system using the Simple Additive Weighting (SAW) method which serves to help the Cendrawasi Expeditionary company get recommendations for priority delivery of goods. The SAW method is very appropriate to be used as a decision support tool where in this study three alternative choices of goods that must be delivered first were obtained, namely plywood with a preference value of 99,6, mattress with a preference value of 83,55 , and PVC pipes with a preference value of 79,35.
\end{abstract}

Keywords: Goods; DSS; SAW; Method; Delivery

\section{INTRODUCTION}

Currently, along with the development and progress of the times and the demands of high mobility, transportation services have become quite an important need for entrepreneurs, shops, panglongs, and individuals to send or move goods. Therefore, many people use transportation services to help ease the work in the process of moving goods. For customers who want to use transportation services, but have limited distance and time and don't want to be complicated with goods that have been purchased, they can use transportation services.

Cendrawasi Expedition is a transportation service company located in Pematangsiantar city that opens a business of goods transportation services for all needs. Delivery of goods carried out at this company uses a truck mode of transportation for delivery of goods via land. The types of goods sent through this company vary greatly, such as plywood, mattresses, pipes, concrete, and other items.

In daily activities, Cendrawasi Expeditions always try to provide excellent service to every customer, by ensuring the vehicle is always in good condition and trying to always be on time in the delivery of goods. However, currently, in terms of shipping goods, the Cendrawasi Expeditionary Company still does not use a decision support system approach in prioritizing the goods to be delivered. For the process of delivering goods to customers to be carried out effectively, a decision support system is designed that functions to determine the priority of goods to be delivered first.

With the advancement of information technology, it is now possible to assist Cendrawasi Expeditions in determining the goods to be sent first. This is made possible by the development of hardware technology accompanied by the development of software, as well as the ability to combine several decision-making techniques. To make it easier to determine the priority of delivering the goods, a decision support system is designed in choosing the fastest delivery priority that can assist in determining the priority of sending goods on the Cendrawasi Expedition. The method used in this decision support system is the Simple Additive Weighting (SAW) method. This method was chosen because the SAW method has been used in various decision-making problems. By using this decision support system, the delivery of goods can be carried out regularly.

* Corresponding author

This is an Creative Commons License This work is licensed under a Creative

Commons Attribution-NoDerivatives 4.0 International License. 


\section{Journal of Computer Networks, Architecture and High Performance Computing}

Submitted : Nop 2, 2021

Volume 3, Number 2, July 2021

https://doi.org/10.47709/cnahpc.v3i2.1154

Accepted : Nop 3, 2021

Published : Nop 4, 2021

\section{LITERATURE REVIEW}

In various fields of life today, the use of technology has an important role (Mulia Siregar \& Sugara, 2018; Purba \& Siregar, 2020; S et al., 2020; Siregar, 2018; Tamba, Batubara, et al., 2019). Every organization increasingly needs information to be used as a basis in making decisions that involve the use of computer technology (Aisyah \& Purba, 2019; Purba, 2018; Sahat Sonang, 2018; Simatupang, 2018; Tamba, Wulandari, et al., 2019), (Salim, 2018).

Decision Support System (DSS) is one aspect of information systems that have been widely used to help people make better decisions in the short, medium, and long term. Many assessments have been made that are not only related to business activities but also other fields, such as education and so on (Purba \& Siregar, 2020; S et al., 2020; Sihombing, Nasution, et al., 2021; Sihombing, Siregar, et al., 2021; Sirait et al., 2021; Siregar, Sihombing, et al., 2021; Siregar, Sonang, et al., 2021). This is very useful when applied to determining the priority of delivering goods so that the process of delivering goods to customers by Cendrawasi Expeditions can be carried out effectively.

The Simple Additive Weighting (SAW) method is the most basic and most widely used strategy. This method is also the simplest to implement because the algorithm is not too difficult. The weighted addition method is another name for the SAW method (Sihombing, Siregar, et al., 2021), (Simatupang, 2018). The main principle of the SAW method is to calculate the total weight of all performance ratings for each alternative across all criteria. By using this method is expected to produce appropriate decision support recommendations (Esterlin Febrianti Telaumbanua et al., 2021; Najar et al., 2021).

\section{METHOD}

The steps taken in building a decision support system for determining goods delivery priority for transportation service companies using the SAW Method are presented in Figure 1. The research stage begins with collecting data on goods to be delivered on the Cendrawasi expedition which is followed by determining the criteria and weights for each criterion. Then the SAW method is used in processing the data that has been collected to get the priority of the goods to be delivered first.

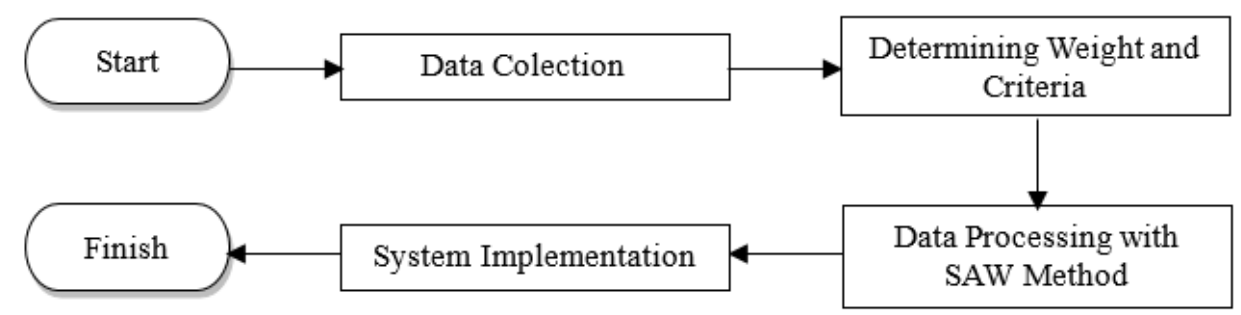

Fig. 1 Research Framework

Data processing using the SAW method is carried out by starting from the formulation of the decision matrix from the data of goods to be delivered, then proceeding with normalizing the decision matrix. The next step is to calculate the average value of the normalized data and continue by multiplying the normalized matrix $(\mathrm{R})$ with the preference weight value. Next, steps are taken to obtain a preference value for each alternative (Vi), so that a larger value of Vi indicates that the alternative is an item that has priority to be delivered first.

The criteria used in the implementation of the preference selection index method on determining goods delivery priority for transportation service companies using the SAW Method consist of the criteria listed in table 1.

Table 1

Criteria Used

\begin{tabular}{cll}
\hline Criteria & Information & Type \\
\hline C1 & Amount & Benefit \\
C2 & Weight & Benefit \\
C3 & Delivery Distance & Benefit \\
C4 & Cost & Benefit \\
\hline
\end{tabular}


Journal of Computer Networks, Architecture and High Performance Computing

Submitted : Nop 2, 2021

Volume 3, Number 2, July 2021

https://doi.org/10.47709/cnahpc.v3i2.1154

Accepted : Nop 3, 2021

Published : Nop 4, 2021

The data to be processed in this study which consists of alternative data and the value of the criteria for each alternative are presented in table 2. In table 2 there are 6 alternative data for goods to be delivered contained in the Cendrawasi Expedition.

Table 2

Item Data to be Delivered

\begin{tabular}{clcccc}
\hline Alternatives & \multicolumn{1}{c}{ Items } & $\begin{array}{c}\text { Amount } \\
(\mathrm{Pcs})\end{array}$ & $\begin{array}{c}\text { Weight } \\
(\mathrm{Kg})\end{array}$ & $\begin{array}{c}\text { Delivery } \\
\text { Distance }(\mathrm{Km})\end{array}$ & $\begin{array}{c}\text { Cost } \\
\text { (Thousand) }\end{array}$ \\
\hline A_01 & Steel Bar & 300 & 600 & 3 & 220 \\
A_02 & PVC Pipe & 200 & 800 & 1 & 800 \\
A_03 & Plywood & 350 & 950 & 3 & 630 \\
A_04 & Mattress & 20 & 800 & 5 & 850 \\
A_05 & Roof & 200 & 750 & 4 & 220 \\
A_06 & Cupboard & 30 & 540 & 2 & 255 \\
\hline
\end{tabular}

\section{RESULT}

To get a priority recommendation of goods to be delivered first, data processing with the SAW method is carried out by starting from the formulation of the decision matrix from the data of goods to be sent with the following $\mathrm{X}$ matrix.

$$
X=\left[\begin{array}{cccc}
300 & 600 & 3 & 220 \\
200 & 800 & 1 & 800 \\
350 & 950 & 3 & 630 \\
20 & 800 & 5 & 850 \\
200 & 750 & 4 & 220 \\
30 & 540 & 2 & 255
\end{array}\right]
$$

For further normalization of the decision matrix above, which is done with the following steps.

a. A_01 (Steel Bar)

$$
\begin{aligned}
& R_{1} \frac{300}{\max \{300,200,350,20,200,30\}}=\frac{300}{350}=0,85 \\
& R_{2} \frac{600}{\max \{600,800,950,800,750,540\}}=\frac{600}{950}=0,63 \\
& R_{3} \frac{3}{\max \{3,1,3,5,4,2\}}=\frac{3}{5}=0,6 \\
& R_{4} \frac{220}{\max \{220,800,630,850,220,255\}}=\frac{220}{850}=0,25
\end{aligned}
$$

b. A_02 (PVC Pipe)

$$
\begin{aligned}
& R_{21} \frac{200}{\max \{300,200,350,20,200,30\}}=\frac{200}{350}=0,57 \\
& R_{22} \frac{800}{\max \{600,800,950,800,750,540\}}=\frac{800}{950}=0,84 \\
& R_{23} \frac{1}{\max \{3,1,3,5,4,2\}}=\frac{1}{5}=0,2 \\
& R_{24} \frac{800}{\max \{220,800,630,850,220,255\}}=\frac{800}{850}=0,94
\end{aligned}
$$

c. A_03 (Plywood)

$$
\begin{aligned}
& R_{31} \frac{350}{\max \{300,200,350,20,200,30\}}=\frac{350}{350}=1 \\
& R_{32} \frac{950}{\max \{600,800,950,800,750,540\}}=\frac{950}{950}=1
\end{aligned}
$$


Journal of Computer Networks, Architecture and High Performance Computing

Submitted : Nop 2, 2021

Volume 3, Number 2, July 2021

https://doi.org/10.47709/cnahpc.v3i2.1154

Accepted : Nop 3, 2021

Published : Nop 4, 2021

$$
\begin{aligned}
& R_{33} \frac{3}{\max \{3,1,3,5,4,2\}}=\frac{3}{5}=0.6 \\
& R_{34} \frac{630}{\max \{220,800,630,850,220,255\}}=\frac{630}{850}=0,74
\end{aligned}
$$

d. A_04 (Mattress)

$R_{41} \frac{20}{\max \{300,200,350,20,200,30\}}=\frac{20}{350}=0.05$

$R_{42} \frac{800}{\max \{600,800,950,800,750,540\}}=\frac{800}{950}=0.84$

$R_{43} \frac{5}{\max \{3,1,3,5,4,2\}}=\frac{5}{5}=1$

$R_{44} \frac{850}{\max \{220,800,630,850,220,255\}}=\frac{850}{850}=1$

e. A_05 (Roof)

$$
\begin{aligned}
& R_{51} \frac{200}{\max \{300,200,350,20,200,30\}}=\frac{200}{350}=0.57 \\
& R_{52} \frac{750}{\max \{600,800,950,800,750,540\}}=\frac{750}{950}=0.78 \\
& R_{53} \frac{4}{\max \{3,1,3,5,4,2\}}=\frac{4}{5}=0.8 \\
& R_{54} \frac{220}{\max \{220,800,630,850,220,255\}}=\frac{220}{850}=0.25
\end{aligned}
$$

f. A_06 (Cupboard)

$$
\begin{aligned}
& R_{41} \frac{30}{\max \{300,200,350,20,200,30\}}=\frac{30}{350}=0.08 \\
& R_{42} \frac{540}{\max \{600,800,950,800,750,540\}}=\frac{240}{950}=0.56 \\
& R_{43} \frac{2}{\max \{3,1,3,5,4,2\}}=\frac{2}{5}=0,4 \\
& R_{44} \frac{255}{\max \{220,800,630,850,220,255\}}=\frac{255}{850}=0,3
\end{aligned}
$$

So based on the results of the above calculations, a normalized matrix is obtained as presented below.

$$
\mathrm{R}=\left[\begin{array}{cccc}
0,85 & 0,63 & 0,6 & 0,25 \\
0,57 & 0,84 & 0,2 & 0,94 \\
1 & 1 & 0,6 & 0,74 \\
0,05 & 0,84 & 1 & 1 \\
0,57 & 0,78 & 0,8 & 0,25 \\
0,08 & 0,56 & 0,4 & 0,3
\end{array}\right]
$$

Furthermore, the W X R matrix multiplication and the addition of the multiplication results are made to obtain the best alternative by ranking the largest values as follows.

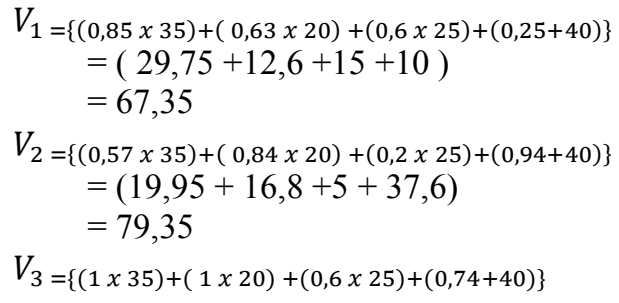




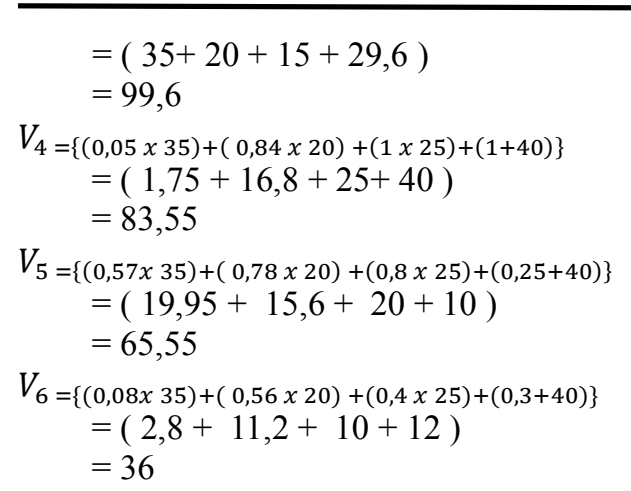

From the multiplication of the $\mathrm{W} \times \mathrm{R}$ matrix, the results are as presented in table 3 .

Table 3

Multiplication Result Matrix W x R

\begin{tabular}{clc}
\hline Alternatives & \multicolumn{1}{c}{ Items } & $\mathrm{V}_{\mathrm{i}}$ Value \\
\hline A_01 & Steel Bar & 67,35 \\
A_02 & PVC Pipe & 79,35 \\
A_03 & Plywood & 99,6 \\
A_04 & Mattress & 83,55 \\
A_05 & Roof & 65,55 \\
A_06 & Cupboard & 36 \\
\hline
\end{tabular}

DISCUSSIONS

Based on the results of the multiplication of the $\mathrm{W} x \mathrm{R}$ matrix contained in table 3 , the goods that are recommended to be delivered first are the goods that have the greatest Vi value. The order of the largest Vi values can be seen in Fig 2 .

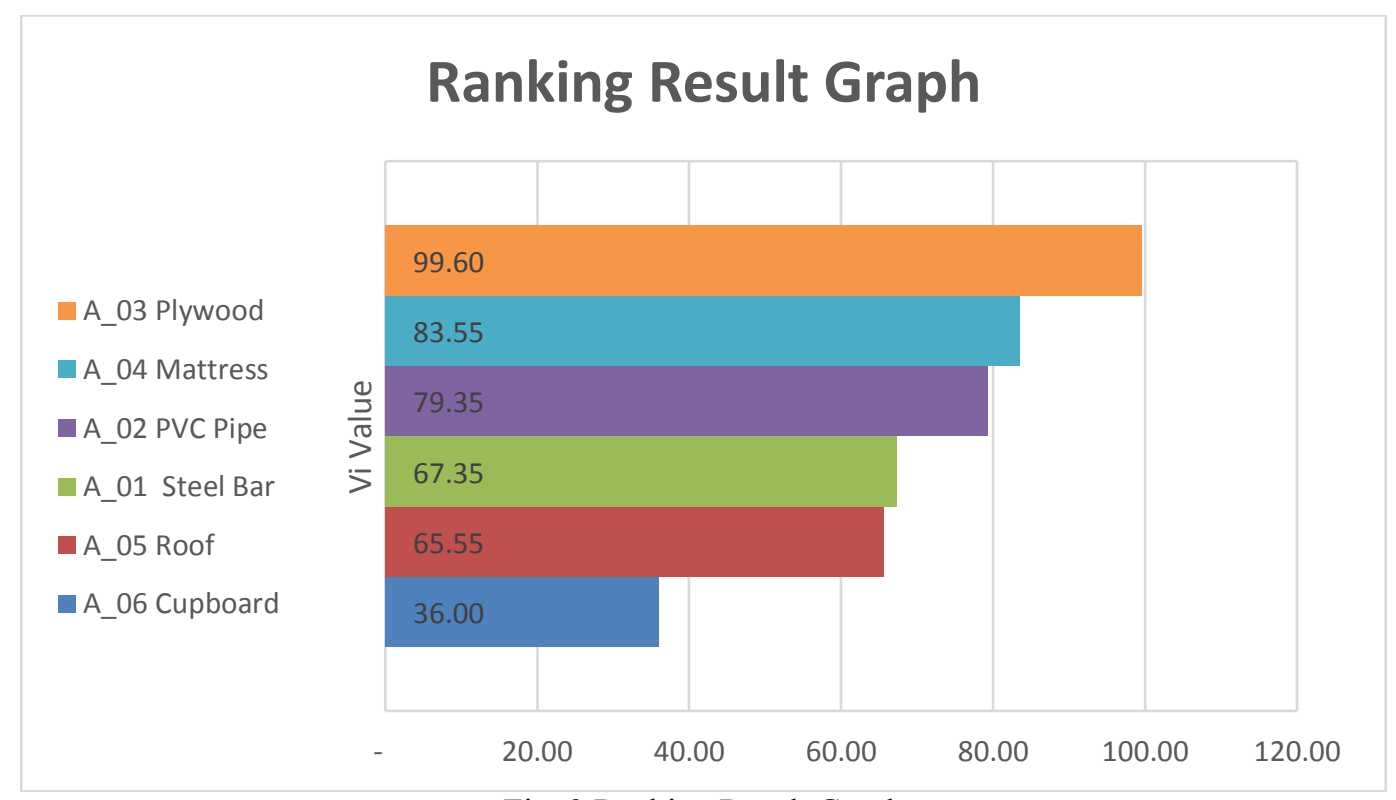

Fig. 2 Ranking Result Graph 


\section{Journal of Computer Networks, Architecture and High Performance Computing}

Volume 3, Number 2, July 2021

https://doi.org/10.47709/cnahpc.v3i2.1154
Submitted : Nop 2, 2021

Accepted : Nop 3, 2021

Published : Nop 4, 2021

\section{CONCLUSION}

The Decision Support System (DSS) in Determining Goods Delivery Priority for Transportation Service Companies Using the SAW Method is designed to facilitate transportation in selecting and assisting in deciding which goods delivery services and goods will be delivered first. Decision Support System using the Simple Additive Weighting Method is the right method to be used in the selection with multiple attributes and the results of the analysis are very good and rational. The results of the DSS calculation using the SAW method in this study obtained three alternative choices of the best used cars, namely Plywood with a preference value of 99,6, Mattresses with a preference value of 83,55 and PVC Pipe with a preference value of 79,35.

\section{REFERENCES}

Aisyah, S., \& Purba, W. (2019). Aplikasi Sistem Pendukung Keputusan Penilaian Kinerja Karyawan Menggunakan Metode Profile Matching. Jurnal Mahajana Informasi, 4(2), 16-20.

Esterlin Febrianti Telaumbanua, Sihombing, V., \& Deci Irmayani. (2021). Rancang Bangun Aplikasi Deteksi Tepi Citra Digital Menggunakan Algoritma Prewitt. Jurnal Teknik Informasi Dan Komputer (Tekinkom), 4(1), 9-13. https://doi.org/10.37600/tekinkom.v4i1.214

Mulia Siregar, V. M., \& Sugara, H. (2018). Implementation of artificial neural network to assesment the lecturer's performance. IOP Conference Series: Materials Science and Engineering, 420(1), 012112. https://doi.org/10.1088/1757-899X/420/1/012112

Najar, A., Sihombing, V., \& Munandar, M. H. (2021). Sistem Pendukung Keputusan Perekrutan Anggota Bem Menggunakan Metode Saw Dan Topsis. Jurnal Teknik Informasi Dan Komputer (Tekinkom), 4(1), 18-24. https://doi.org/10.37600/tekinkom.v4i1.233

Purba, A. T. (2018). Sistem Pendukung Keputusan Dalam Penerimaan Mahasiswa Baru Dengan Metode Analytical Hierarchy Process (AHP). Jurnal Tekinkom, 1(1), 1-7.

Purba, A. T., \& Siregar, V. M. M. (2020). Sistem Penyeleksi Mahasiswa Baru Berbasis Web Menggunakan Metode Weighted Product. Jurnal Teknik Informasi Dan Komputer (Tekinkom), 3(1), 1. https://doi.org/10.37600/tekinkom.v3i1.117

S, S. S., Purba, A. T., \& Siregar, V. M. M. (2020). Sistem Pendukung Keputusan Kelayakan Pemberian Pinjaman Kredit Menggunakan Metode Topsis Pada Cum Caritas HHKBP Pematangsiantar. Jurnal Teknik Informasi Dan Komputer (Tekinkom), 3(1), 1. https://doi.org/10.37600/tekinkom.v3i1.117

Sahat Sonang. (2018). Implementasi K-Means Dalam Evaluasi Kinerja Dosen Politeknik Bisnis Indonesia. Jurnal Tekinkom, 1(1), 32-40. https://doi.org/10.1017/CBO9781107415324.004

Salim, M. A. (2018). Sistem Pendukung Keputusan Pemilihan Penerima Bantuan Perbaikan Rumah Menggunakan Metode Simple Additive Wieghting (SAW) Studi Kasus Kelurahan Tambelan Sampit Kota Pontianak. Jurnal SISTEMASI, 7(2), 120-131. https://doi.org/DOI : https://doi.org/10.32520/stmsi.v7i2.293.g124

Sihombing, V., Nasution, Z., Al Ihsan, M. A., Siregar, M., Munthe, I. R., Siregar, V. M. M., Fatmawati, I., \& Asfar, D. A. (2021). Additive Ratio Assessment (ARAS) Method for Selecting English Course Branch Locations. Journal of Physics: Conference Series, 1933(1), 012070. https://doi.org/10.1088/1742-6596/1933/1/012070

Sihombing, V., Siregar, V. M. M., Tampubolon, W. S., Jannah, M., Risdalina, \& Hakim, A. (2021). Implementation of simple additive weighting algorithm in decision support system. IOP Conference Series: Materials Science and Engineering, 1088(1), 012014. https://doi.org/10.1088/1757-899X/1088/1/012014

Simatupang, J. (2018). Sistem Pendukung Keputusan Penentuan Karyawan Terbaik Menggunakan Metode Saw Studi Kasus Amik Mahaputra Riau. Jurnal Intra-Tech, 2(1), 73-82.

Sirait, S., Saragih, D. Y., Sugara, H., Yunus, M., Sumaizar, Hanafiah Ali, M., Mulia Siregar, V. M., Indrawan, I., Anwar, U., \& Defliyanto, D. (2021). Selection of the Best Administrative Staff Using Elimination Et Choix Traduisant La Realite (ELECTRE) Method. Journal of Physics: Conference Series, 1933(1), 012068. https://doi.org/10.1088/1742-6596/1933/1/012068

Siregar, V. M. M. (2018). Sistem Pendukung Keputusan Penentuan Insentif Bulanan Pegawai Dengan Menggunakan Metode Naïve Bayes. SISTEMASI, 7(2), 87-94.

Siregar, V. M. M., Sihombing, V., Siahaan, N., Indra Kumalasari, M., Siregar, M. Y., Sagala, E., \& Toni. (2021). 
Journal of Computer Networks, Architecture and High Performance Computing

Volume 3, Number 2, July 2021

https://doi.org/10.47709/cnahpc.v3i2.1154

Submitted : Nop 2, 2021

Accepted : Nop 3, 2021

Published : Nop 4, 2021

Implementation of ELECTRE Method for Decision Support System. IOP Conference Series: Materials Science and Engineering, 1088(1), 012027. https://doi.org/10.1088/1757-899X/1088/1/012027

Siregar, V. M. M., Sonang, S., Purba, A. T., Sugara, H., \& Siagian, N. F. (2021). Implementation of TOPSIS Algorithm for Selection of Prominent Student Class. Journal of Physics: Conference Series, 1783(1), 012038. https://doi.org/10.1088/1742-6596/1783/1/012038

Tamba, S. P., Batubara, M. D., Purba, W., Sihombing, M., Mulia Siregar, V. M., \& Banjarnahor, J. (2019). Book data grouping in libraries using the k-means clustering method. Journal of Physics: Conference Series, 1230(1), 012074. https://doi.org/10.1088/1742-6596/1230/1/012074

Tamba, S. P., Wulandari, P., Hutabarat, M., Christina, M., \& Oktavia, A. (2019). PENGGUNAAN METODE TOPSIS (TECHNIQUE FOR ORDER PREFERENCE BY SIMILARITY TO IDEAL SOLUTION) UNTUK MENENTUKAN KUALITAS BIJI KOPI TERBAIK BERBASIS ANDROID. Jurnal Mantik Penusa, 3(1), 7381. 